\title{
Discovered online: Hibiscus hareyae sp. nov. of sect. Lilibiscus (Malvaceae), threatened in coastal thicket at Lindi, Tanzania
}

\author{
Lex A. J. Thomson ${ }^{1} \&$ Martin Cheek $^{2}$
}

Summary. The spectacular new species with horticultural potential described in this paper, Hibiscus hareyae L.A.J.Thomson \& Cheek, was identified during an assessment of online digitised botanical specimens of H. schizopetalus (Dyer) Hook.f. as part of a review of species in Hibiscus sect. Lilibiscus Hochr. A short updated description and delimitation of the horticulturally important sect. Lilibiscus is presented. Flowering and fruiting specimens of Hibiscus hareyae are readily distinguished from $H$. schizopetalus by their short $(0.4-2(-4.5) \mathrm{cm}$ long, non-articulated peduncle-pedicels vs $(6-) 8-$ $11(-14) \mathrm{cm}$ long, articulated peduncle-pedicels, and larger, broader epicalyx bracts $(1.5-4 \times 1-1.2 \mathrm{~mm}$ vs $0.6-1.5 \times$ $0.1-0.3(-0.5) \mathrm{mm})$, the epicalyx forming a shallow cup $0.5-1 \times 2-3 \mathrm{~mm}$ vs bracts appearing free. The absence of an articulation of the peduncle-pedicel of H. hareyae is unique within sect. Lilibiscus. The species is also well-marked from H. schizopetalus by other morphological differences in corolla and foliage, and in ecology and geography. Hibiscus hareyae has a restricted natural distribution as an element in deciduous coastal thicket, usually on coral rag formations, sometimes in or near mangrove, in Lindi Province, southern Tanzania. It ranges from the Indian Ocean coast to as much as $20 \mathrm{~km}$ inland, from about $8.5^{\circ} \mathrm{S}$ to $10^{\circ} \mathrm{S}($ c. $140 \times 20 \mathrm{~km}$ ) and is assessed as Vulnerable (VU B2ab(iii)). Hibiscus hareyae has high ornamental potential but is unknown in cultivation.

Key Words. Africa, conservation, coral rag, Hibiscus schizopetalus, horticulture.

\section{Introduction}

In the early 1870's, Dr John Kirk found a dry-season deciduous Hibiscus with laciniate petals growing on a dry rocky slope near Kilwa Kisiwani in south-east Tanzania, then a significant port in E Africa. Later, in September 1873 he found a similar Hibiscus, also with laciniate petals growing 300 miles away in a "damp, mountain glen in the Wanika Hills", near Mombasa in south-east Kenya. Kirk considered these to be variants of the same species, with morphological differences being attributed to the different environmental conditions in which the Hibiscus were growing, and he presumed that geographical and morphological intermediates existed (Kirk \& Oliver 1877). Public attention was first drawn to the plants by Kirk \& Oliver (1877), and they were initially considered as a variety of Hibiscus rosa-sinensis L., (Boulger 1879; Masters 1879; Thistleton-Dyer 1879) before the variety was elevated to species rank as $H$. schizopetalus (Dyer) Hook.f. (Hooker 1880). Seed of the Kenyan plants came into cultivation in London in 1874 and it was subsequently spread throughout the world as a tropical ornamental plant. In 1874 Kirk sent unnumbered specimens of both the Wanika Hills and Kilwa collections to Kew (Cheek 1989) where these were mounted on a single herbarium sheet and later assigned barcodes K000240991 and K000240492. In January 1884 Kirk (1884) sent two more specimens to Kew of the southern Tanzanian Hibiscus, collected from Lindi in Nov. 1877 and in July 1877: these were mounted on another herbarium sheet (assigned K000240493 and K000593146). Subsequently, eight additional botanical collections were made of the southern Tanzanian Hibiscus, which was found to be a new species. The new species, here described as Hibiscus hareyae L.A.J.Thomson \& Cheek, was identified during an online assessment of digital images of botanical specimens of $H$. schizopetalus (Dyer) Hook.f. as part of a review of sect. Lilibiscus by the first author and confirmed by examination of herbarium material

The genus Hibiscus L., as currently delimited, with 1449 names listed by IPNI (continuously updated), comprises 422 accepted species (POWO 2020). Species of the genus are pantropical and subtropical, but with some representation in the temperate zone. They vary from annual herbs to small trees. The flowers usually have an epicalyx with $>5$ or usually many more, free or partly united, usually narrowly triangular, nonfoliose, non-fleshy, bracteoles. The styles bear five branches, each terminating in a capitate stigma. The fruit is a 5-valved, dehiscent loculicidal capsule, each locule holding three or more seeds. New taxa of

Accepted for publication 14 July 2020. Published online 9 December 2020

1 Faculty of Science, Health, Education and Engineering, University of the Sunshine Coast, Maroochydore, Queensland, 4558, Australia.

2 Herbarium, Royal Botanic Gardens, Kew, Richmond, Surrey, TW9 3AE, UK. e-mail: m.cheek@kew.org 
Hibiscus are still steadily being discovered and published e.g. Hibiscus vitifolius subsp. lukei Mwachala (Mwachala \& Cheek 2003), H. bennettii L.A.J.Thomson \& Braglia (Thomson \& Braglia 2019) and H. fabianae Cheek (Cheek et al. 2020)

\section{Sect. Lilibiscus Hochr.}

Shrubs, sometimes scandent, or small trees, usually with unlobed, ovate, glossy leaves. Flowers single, axillary, usually with an articulated peduncle. Involucre (epicalyx) of 5-10, more or less linear or narrowly triangular bracts, usually shorter than the calyx and never fused with each other or with the calyx. Calyx united into a tube, lobes shorter than tube. Involucre and calyx glabrous or only slightly tomentose with stellate and simple hairs. Corolla large and bright, the petals reflexed at anthesis leaving the staminal column conspicuously exserted. Fruit capsular, usually obovoid and glabrous or scabrous, but never woolly. Seeds smooth, verrucate, or hairy.

Section Lilibiscus, comprising 23 species (several of which have previously been treated as subspecies), is restricted mainly to islands in the Indian and Pacific Oceans. It is monophyletic and sister to Sect. Hibiscus according to Pfeil et al. (2002) although with poor sampling. According to Thomson \& Braglia (2019), nine species are known from Hawaii, those with predominantly white flowers being H. waimeae A.Heller, H. hannerae O.Deg. \& I.Deg., H. arnottianus A.Gray, H. immaculatus Roe, H. punaluuensis Skotsb. and those with orange or red flowers being $H$. kokio Hillebr. ex Wawra, H. kahili C.N.Forbes, H. saintjohnianus Roe, H. clayii O.Deg. \& I.Deg. Four species have been recorded from Fiji: H. storckii Seem., H. bennettii, H. bragliae L.A.J.Thomson, H. macverryi L.A.J.Thomson \& Braglia (Thomson \& Braglia 2019). Hibiscus cooperi Hort. has recently been confirmed growing in its native state in the interior of Erromango, Vanuatu (Joe James Rungu, pers. comm.).

In the Indian Ocean, four species (Hibiscus boryanus DC., H. fragilis DC., H. genevii Bojer ex Hook., H. liliflorus Cav.) are known from the Mascarene Islands and from Madagascar five species (H. bernieri Baill., H. grandidier Baill., H. phanerandus Baker, H. perrieri Hochr., H. liliastrum Hochr.), while $H$. schizopetalus and $H$. hareyae, described in this paper, are restricted to the Indian Ocean coast of E Africa. Two taxa, H. rosa-sinensis and H. denisonii Hort. are only known from horticulture. Plants of section Lilibiscus, especially $H$. rosa-sinensis and its hybrids are the most commonly cultivated ornamentals of the genus.

\section{Taxonomic Treatment}

The lectotype of Hibicus schizopetalus (Dyer) Hook.f. is Kirk s.n. (K!, chosen by Cheek (1989)) from Kenya,
Mombasa District. This specimen (Kew barcode K00240991, lectotype) was a mixed collection, with a different element subsequently barcoded K000240492 on the same sheet. Furthermore, the area on the sheet coded K000240492 includes specimens which are a mixture of $H$. schizopetalus and $H$. hareyae sp. nov. The only material of $H$. hareyae on this sheet is the short leafless stalk with a single flower on a short peduncle at the top right of the specimen sheet. The handwritten location 'Kilwa' in the hand of Daniel Oliver, Keeper of the Kew Herbarium, appears misplaced on the sheet and ought to have been pointing to the floral fragment of $H$. hareyae in the top right corner, rather than to the undoubted specimen of H. schizopetalus.

Hibiscus hareyae although superficially similar to $H$. schizopetalus, is a distinctive and well-marked species. Whilst $H$. hareyae is closely related to, and shares many features including two distinctive floral traits with, H. schizopetalus - laciniate petals and pendant flowers - it differs in other taxonomically significant floral and foliar morphological characters (Table 1). These differences with $H$. schizopetalus indicate that it warrants species-level recognition. The absence of an articulated floral stalk is unique in sect. Lilibiscus. The two species have an allopatric distribution with the nearest populations separated by a distance of about $400 \mathrm{~km}$. Examination of specimens of $H$. hareyae from northern Tanzania indicated no evidence of morphological intermediates or gene exchange between populations of the two species.

The name Hibiscus schizopetalus is globally associated with plants of the Kenyan and northern Tanzanian species: this species is now widely planted throughout the tropics and subtropics, and also as a glasshouse/ indoor plant in cooler climates. Planted in gardens as an ornamental it can often persist and become locally naturalised. Naturalised populations deduced from this source were observed in Cameroon in 2007 and Guinea in 2012 (Cheek pers. obs). On the Tropicos website of herbarium specimens of wild plants, of the 38 listed of Hibiscus schizopetalus, 28 are from Central and South America where the species is definitely not native, as is the case also for the records from Gabon and Mozambique (Tropicos.org 2020). We consider that most of the few specimens of $H$. schizopetalus from central-eastern Tanzania are likely to be naturalised or old plantings of $H$. schizopetalus, on this basis. For example the label of one specimen of $H$. schizopetalus from central Tanzania ( $H$. Breyne 5562, BR0000019387017) collected along the Dar es Salam - Morogoro road states that it was introduced and naturalised in gallery forest.

Cheek's (1989) rationale for choice of lectotype is sound and fortuitously minimises any disruption with continuing the existing use of the name Hibiscus schizopetalus. 


\section{Materials and Methods}

The new species was first discovered by the first author by examining online images of herbarium specimens including the Kew Herbarium catalogue (continuously updated), and examining them for morphological disjunctions. Gross morphological measurements were initially made from these images. Finally, herbarium material at $\mathrm{K}$ was examined with a Leica Wild M8 dissecting binocular microscope fitted with an eyepiece graticule measuring in units of $0.025 \mathrm{~mm}$ at maximum magnification. The drawing was made with the same equipment with a Leica 308700 camera lucida attachment. Specimens or their high resolution images were inspected from the following herbaria: BM, DSM, EA, FTG, K, MO and P. Names of species and authors follow IPNI (continuously updated). The format of the description follows those in other papers describing new taxa of Hibiscus Sect. Lilibiscus e.g. Thomson \& Braglia (2019), Cafferty \& Cheek (1996), Cheek et al. (1998). Technical terms follow Beentje \& Cheek (2003). Specimens cited which have been seen are indicated "!". The conservation assessment follows the IUCN (2012) categories and criteria. Herbarium codes follow Index Herbariorum (Thiers, continuously updated). The map was made using simplemappr software (https://www.simplemappr.net/).

\section{New Species}

Hibiscus hareyae L.A.J.Thomson $\mathcal{E}$ Cheek sp. nov. Type: Tanzania, Lindi Province, "Collected July 1877. Lindi, E. Africa, Lat. 9 40' South this extends its habitats a little further South than before", Kirk s.n. (holotype K00240493!) (Fig. 1).

http:/ /www.ipni.org/urn:lsid:ipni.org:names:77213108-1

Syn. Hibiscus schizopetalus auct., non (Dyer) Hook.f. sensu Mwachala (2009: 60) pro parte

Deciduous erect, sprawling, to scandent shrub, $2-4 \mathrm{~m}$ tall, to 6 $\mathrm{m}$ wide, often leafless or near-leafless at onset of flowering. Branches slender, pendulous arching to the ground; bark grey with white blotches. Branchlets light grey-green, becoming waxy-white, smooth or finely ridged, $2-3 \mathrm{~mm}$ diam., internodes $1.2-1.8(-4.5) \mathrm{cm}$ long, glabrous. Leaves deciduous during the dry season; light green above, ovate, oblong or elliptic, 1.8 - 3.0 ($4.7) \times 0.9-1.5-1.8(-3.5) \mathrm{cm}$, apex obtuse-rounded, base obtuse, finally abruptly rounded, nerves palmate at base, midrib with $2-3$ secondary nerves on each side of the midrib, nerves prominent below; teeth $(1-) 3-5$ (10) per side, large rounded-crenate , $1(-2) \times$ c. $2-3$ (5) $\mathrm{mm}$, margin slightly thickened, lined with appressed, simple, stout, colourless unicellular hairs c. $0.3 \mathrm{~mm}$ long, abaxial surface of leaf with pale golden stellate hairs thinly scattered, $0.3(-0.5) \mathrm{mm}$ diam., arms appressed, stout. Stipules brown-purple, glossy, broadly triangular, $0.5-1.25 \times 0.5-1 \mathrm{~mm}$, sparsely hairy, persistent for several nodes from stem apex. Petiole $3-6(-50) \mathrm{mm}$ long, slightly canaliculate, densely pubescent with long, white, sinuous simple hairs $0.3 \mathrm{~mm}$ long, tapering to a long acute apex. Flowers often on leafless branches, 6 $8.5 \mathrm{~cm}$ wide, solitary or more typically clustered in upper leafless axils on pendant peduncle-pedicels. Pedunclepedicels stout $0.4-2(-4.5) \mathrm{cm}$ long, longitudinally ridged, sparsely puberulent with a mixture of stellate and simple hairs, stellate hairs 3-7-armed, $1-2.5 \mathrm{~mm}$ wide, simple hairs patent, $0.5-1 \mathrm{~mm}$ long, when immature densely papillate with multicellular papillae $0.05 \mathrm{~mm}$ long. Epicalyx bracts $7-8$, united at base forming a shallow cup $0.5-1 \times 2-3 \mathrm{~mm}$, bracts pale green, $1.5-4$ $\times 1-1.2 \mathrm{~mm}$, narrow-lanceolate, outer surface sparsely covered (c. $10 \%$ of surface) mainly in stellate hairs $3-4$ armed, 1 - $2 \mathrm{~mm}$ long, simple hairs $0.5-1.5 \mathrm{~mm}$ long. Calyx pale green, slightly campanulate, tube c. $2 \mathrm{~cm}$ long $\times 4 \mathrm{~mm}$ wide at base to $1 \mathrm{~cm}$ wide at apex, $3-4$-lobed, lobes triangular $4-5 \mathrm{~mm}$ long, outer surface sparsely covered $(10-20 \%$ of surface) in mainly simple, patent hairs $0.5-1 \mathrm{~mm}$ long, with a few stellate hairs (as epicalyx). Petals 5, shortly clawed, claw c. $0.3 \times 0.2 \mathrm{~cm}$, laterally compressed, blade ovate-elliptic, c. $3-3.5 \times 2.5-$ $3 \mathrm{~cm}$, pinnatifid, divided $1 / 2-2 / 3$ to the midline, c. 8 segments each side, with the distal segments $1-2 \mathrm{~mm}$ wide and bifid or trifid, basal segment pair, oblong, 1 $1.3 \times 0.5 \mathrm{~cm}$, segments slightly recurved, adaxial surface deep rose-pink or burgundy red, with an extensive (50 $75 \%$ ) white/pale pink basal zone, abaxial surface rosecrimson, also described as red (Kayombo 4590, MO) or red and yellow (Semsei S633, K). Staminal column (4-) 5 $-6 \mathrm{~cm}$ long, rose pink, slender, antheriferous in terminal $25-30 \%$. Stamens $100-110$, filaments $7-10 \mathrm{~mm}$ long, pink, anthers orange, oblong $7-9 \times 5-6 \mathrm{~mm}$, pollen yellow or orange. Style exserted c. $1 \mathrm{~cm}$ beyond androecium, then dividing into 5, slender, spreading branches, c. $14-20 \mathrm{~mm}$ long, crimson. Stigma pads minute-capitate, c. $1 \mathrm{~mm}$ diameter, crimson. Fruit 5valved capsule, c. $2.2 \mathrm{~cm}$ long $\times 0.8 \mathrm{~cm}$ wide, pale-green, valves acuminate. Seeds unknown. Figs $1-3$.

RECOGNITION. Within Hibiscus, H. hareyae and $H$. schizopetalus are the only two species with laciniate petals. Hibiscus hareyae is readily distinguished from H. schizopetalus by its much shorter and non-articulated peduncle-pedicels $(0.4-2 \mathrm{~cm}$ long vs $8-14 \mathrm{~cm}$ long and articulated); longer and broader epicalyx bracts, $(1.5-4 \times 1-1.2 \mathrm{~mm}$ vs $0.6-1.5 \times 0.1-0.3(0.5) \mathrm{mm}$, the epicalyx forming a shallow cup $0.5-1 \times 2-3 \mathrm{~mm}$, vs bracts appearing free (for additional diagnostic characters see Table 1).

DISTRIBUTION. Tanzania (Map 1). The species is endemic to the Kilwa and Lindi Districts (Lindi Region) of southern Tanzania. It is possible that the 
Table 1. Diagnostic differences between Hibiscus hareyae and $H$. schizopetalus.

\begin{tabular}{|c|c|c|}
\hline & Hibiscus hareyae & Hibiscus schizopetalus \\
\hline Peduncle-pedicel & $0.4-2(-4.5) \mathrm{cm}$ long; non-articulated & $(6-) 8-11(-14) \mathrm{cm}$ long, articulated \\
\hline Epicalyx bracts & $\begin{array}{l}\text { Narrowly triangular, } 1.5-4 \times 1-1.2 \mathrm{~mm} \text { long, } \\
\text { persistent, united at base into a shallow cup } 0.5-1 \times \\
2-3 \mathrm{~mm}\end{array}$ & $\begin{array}{l}\text { Linear to narrowly oblong, } 0.6-1.5 \times 0.1-0.3(-0.5) \\
\text { mm long; caducous, sometimes abortive, appearing } \\
\text { free, the base not forming a cup }\end{array}$ \\
\hline Corolla & Petals slightly reflexed, $3-3.5 \times 1-1.5 \mathrm{~cm}$ (near base) & Petals reflexed in an arc, $3.5-5.5 \times 0.5$ (near base) \\
\hline Number of anthers & $100-110$ & $60-80$ \\
\hline Typical leaves & $\begin{array}{l}\text { Deciduous. Ovate, elliptic or oblong, } 1.8-3.0 \times 0.9- \\
1.5 \mathrm{~cm} \text { wide; margin large rounded-crenate leaf } \\
\text { teeth, } 2-3 \mathrm{~mm} \text { across, } 3-5 \text { teeth per margin }\end{array}$ & $\begin{array}{l}\text { Evergreen. Lanceolate to ovate-elliptic, } 3.5-7.5 \times 1.2- \\
4 \mathrm{~cm} \text { wide; margin serrate-dentate (entire toward } \\
\text { rounded base), } 6-10 \text { teeth per margin }\end{array}$ \\
\hline Habit & Erect to scandent shrub, $2-4 \mathrm{~m}$ tall & Shrub scandent, or small forest tree, $2.5-5(-8) \mathrm{m}$ tall \\
\hline Stipules & $\begin{array}{l}\text { Brown-purple, glossy, broadly triangular, sparsely } \\
\text { hairy, } 0.5-1.25 \times 0.5-1 \mathrm{~mm} \text {, persistent for } \\
\text { several nodes from stem apex }\end{array}$ & $\begin{array}{l}\text { White, subulate, densely covered in hairs, } 0.5-1 \times 0.1 \\
\text { mm, rapidly caducous }\end{array}$ \\
\hline Natural distribution & Lindi and Kilwa Provinces, S Tanzania & SE Kenya and NE Tanzania \\
\hline Ecology & $\begin{array}{l}\text { Deciduous coastal thicket usually on coral rag, } \\
\text { sometimes at edge of mangrove }\end{array}$ & Relictual semi-evergreen coastal forests \\
\hline
\end{tabular}

species might yet be found in northern Mozambique but it was not recorded as wild there by Exell (1961). SPECIMENS EXAMINED. TANZANIA. Lindi Province: Kilwa Distr., T8 - N end of Mbarawala Plateau, 7 Nov. 2003, C. J. Kayombo 4590 (MO 5750577 image!); Kilwa Distr., Kilwa South - pt451, 0908S, 3920 E, fl. 25 Nov. 2003, W. R. Q. Luke E O Kibure 9718 (MO5792757 image!, FTG122084 image!) (EA, K000593145!, LMA, NHT); Kilwa Distr., $32 \mathrm{~km} \mathrm{~N}$ of Lindi, Mchinga S, pt 552, fl. 20 Dec. 2003, W. R. Q. Luke E O. Kibure 10203 (FTG122085 image!); Lindi Distr., c. $6.5 \mathrm{~km} \mathrm{~N}$ of Lindi, fl. 9 Dec. 1955, E. Milne-Redhead Eं P. G. Taylor 7481, 9 Dec. 1955 (BR image!, K000593143!, K000593144!); Lindi, “Lat. 9 40' South, this extends its habitats a little further South than before", fl. July 1877, Kirk s.n. (holotype K000240943!); Lindi, fl. Nov. 1877, Kirk s.n. (K000593146!); Lindi, 40 km westlich, 200 - 250 um. Mangrovenrade, fl. 26 Aug. 1934 (Schlieben 5184 (BM!, P06593493 image!); Lindi Region, Lindi Distr., Lindi Creek, 10 00'S, 39 44'E, fl. 15 July 1995, G. P. Clarke 89 (K000593147!); Lindi Distr., Lindi Township, fl. Jan. 1952, Semsei S633 (K000593148!); Lindi, at Mdenga, coastal hills, fl. buds, 26 Feb. 1936, Litchfield 5457 (K000593149!, K000593150!); Lindi Region, Mtama Distr., Sudi Village 10.16019E 39.96873S, fl. 12 Jan. 2020, O. Suleiman, Darbyshire E Shah, Mbailwa 5526 (DSM, K, NHT).

HABITAT. Hibiscus hareyae is found in coastal habitats ("in the mangrove formation" Semsei S633), in the ecotone between mangrove and thicket on coral rag (Suleiman et al. 5526) and in "coastal thicket" (Luke Eे Kibure 9718) or "coastal deciduous bushland" (MilneRedhead E Taylor 7481) on the edge of seasonally-dry watercourses in thicket, and on hillsides (sea-level to $250 \mathrm{~m}$ alt.). There is a single record in "dry forest". Associated species (Suleiman et al. 5526) are Fimbristylis sp.; Euphorbia tirucalli Thunb., Dalbergia melanoxylon Guill. \& Perr., and Erythroxylum emarginatum Thonn.

Temperatures in the Lindi Region are rather constant throughout the year, with the mean daily temperature ranging from $25-28^{\circ} \mathrm{C}$, and mean daily maximum temperature of $31-32^{\circ} \mathrm{C}$, and mean daily minimum temperature of $20-24^{\circ} \mathrm{C}$. The average annual rainfall is around $900 \mathrm{~mm}$ falling between Dec. and April, with a pronounced dry season of $6-7$ months. Tropical cyclones, sometimes severe and reaching category 4, occur infrequently from late Dec. through to mid-April.

Hibiscus hareyae mainly occurs (Kilwa, Lindi and Kiswa areas) on coral rag, a rubble-like limestone formed by uplift of former marine coral reefs.

CONSERVATION STATUS. Hibiscus hareyae is known from 12 specimens and six threat-based locations. We calculate the area of occupancy as $40 \mathrm{~km}^{2}$ using the 4 $\mathrm{km}^{2}$ cells favoured by IUCN (2012). The main location is the town of Lindi, from which (or very nearby) seven collections, from at least five sites have been made. Two of these records refer to the species as occurring in mangrove where it is "very common" (Schlieben 5184 and Semsei S633). Other than these collections, there are few data on frequency, but recent research has reported it as infrequent: during the survey of thicket on coral rag resulting in collection of Suleiman 5526 , $H$. hareyae was only seen at a single site with just 4 or 5 individuals. Although this species was targeted by the survey and other areas of coral rag were studied, no further plants were found despite it being then spectacular in flower (Darbyshire, RBG, Kew, pers. comm. to Cheek Jan. 2020). Threats from agriculture to thicket on coral rag substrate are low because coral rag is uncultivatable. However large areas within the range of the species along the coast have been converted to salt pans which appears to have destroyed 


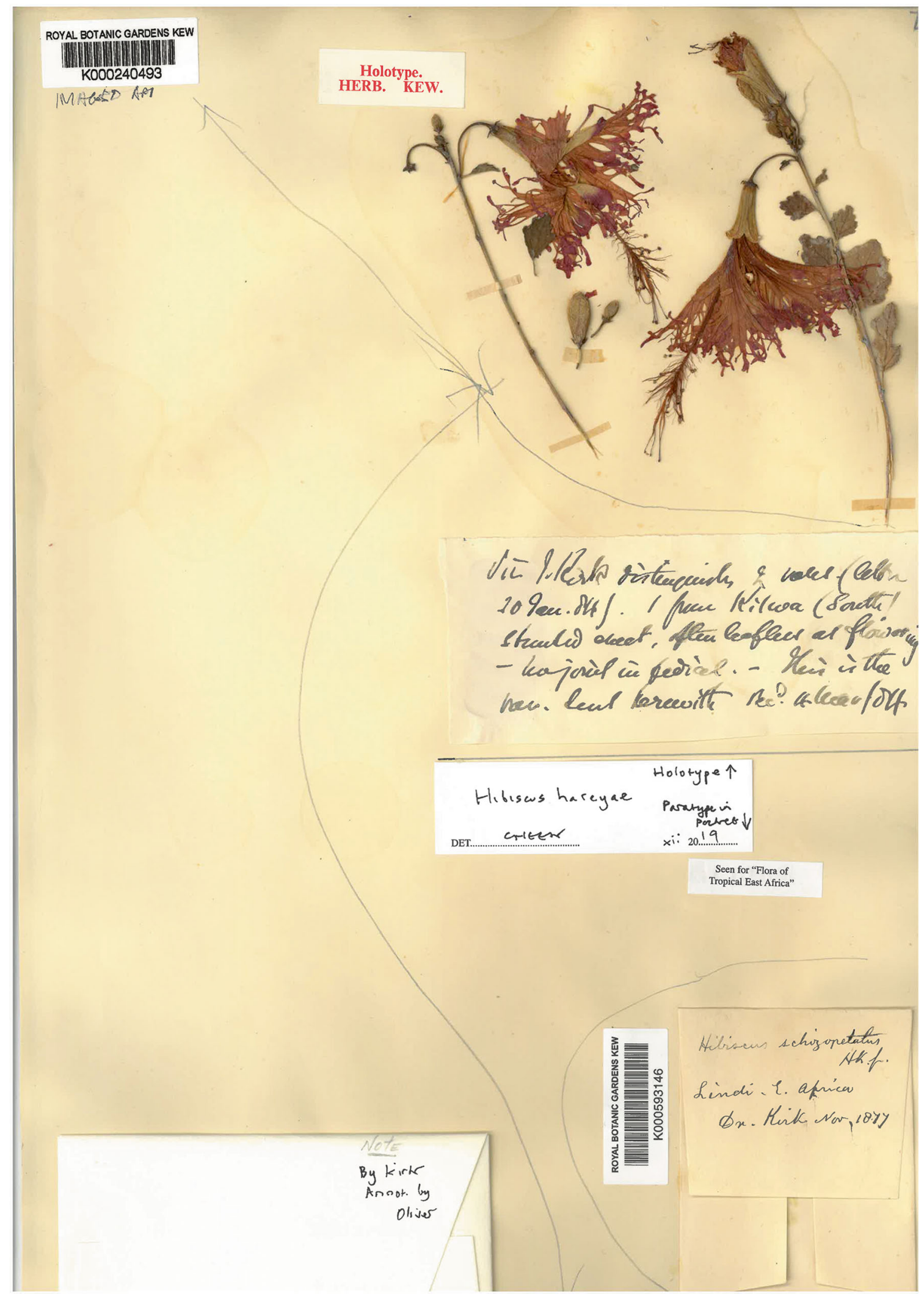

Fig. 1. Hibiscus hareyae. Image of the holotype (K00240493), Kirk S.n. Tanzania, Lindi, July 1877. 


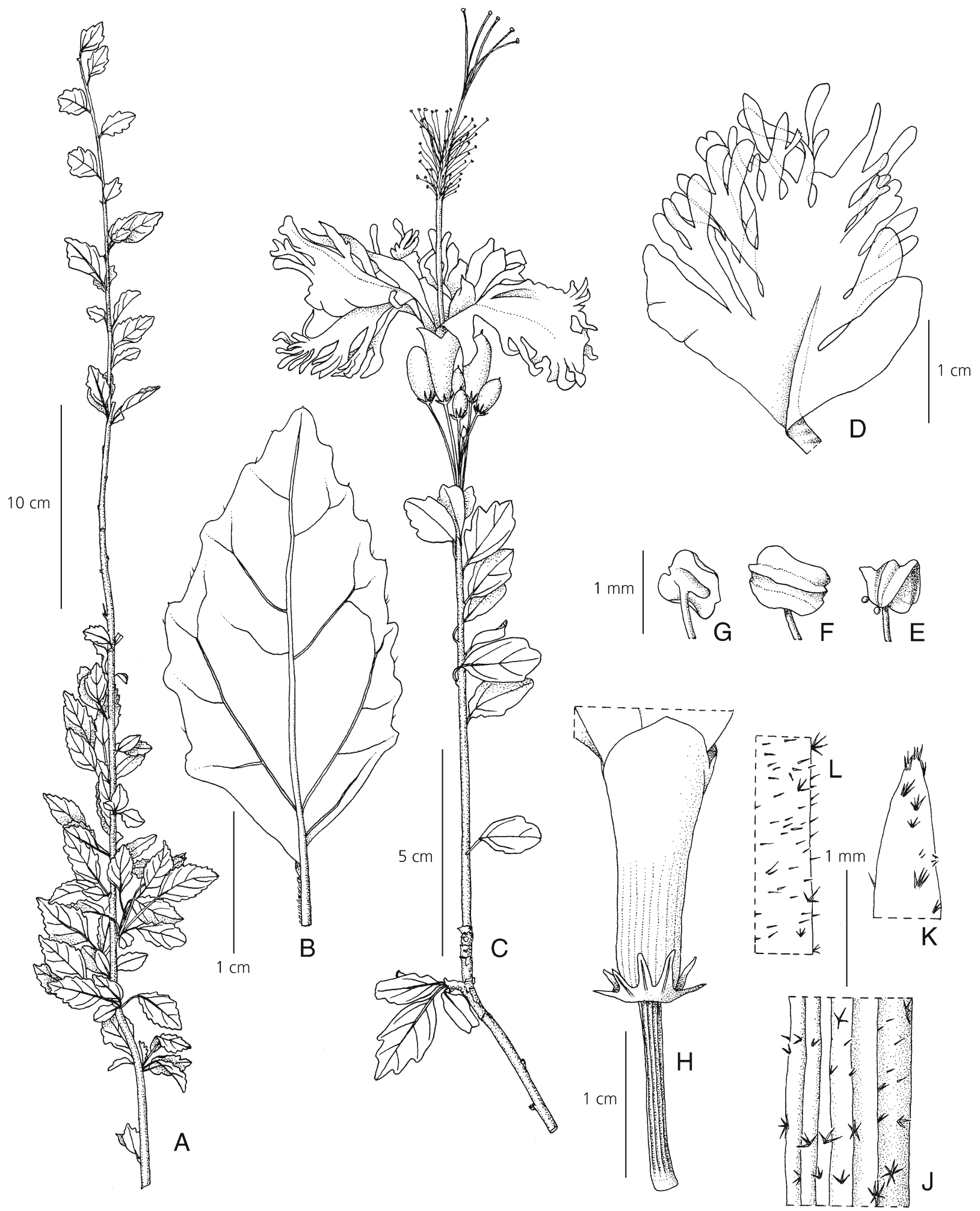

Fig. 2. Hibiscus hareyae. A habit, leafy shoot; B full-sized leaf, abaxial surface; C flowering shoot; D petal; $E$ anther; $F$ anther, inner face; $\mathrm{G}$ anther, dorsal face showing filament insertion; $\mathrm{H}$ pedicel, epicalyx and calyx; J pedicel detail-indumentum; $\mathrm{K}$ calyx margin indumentum; L epicalyx lobe — indumentum. From Milne-Redhead \& Taylor 7481. DRAWN BY ANDREW BROWN.

habitat. Several historic sites at Lindi may have been lost due to house and road construction resulting from expansion of the town. At the site of Suleiman et al. 5526 , much of the habitat had been cleared by cutting. 

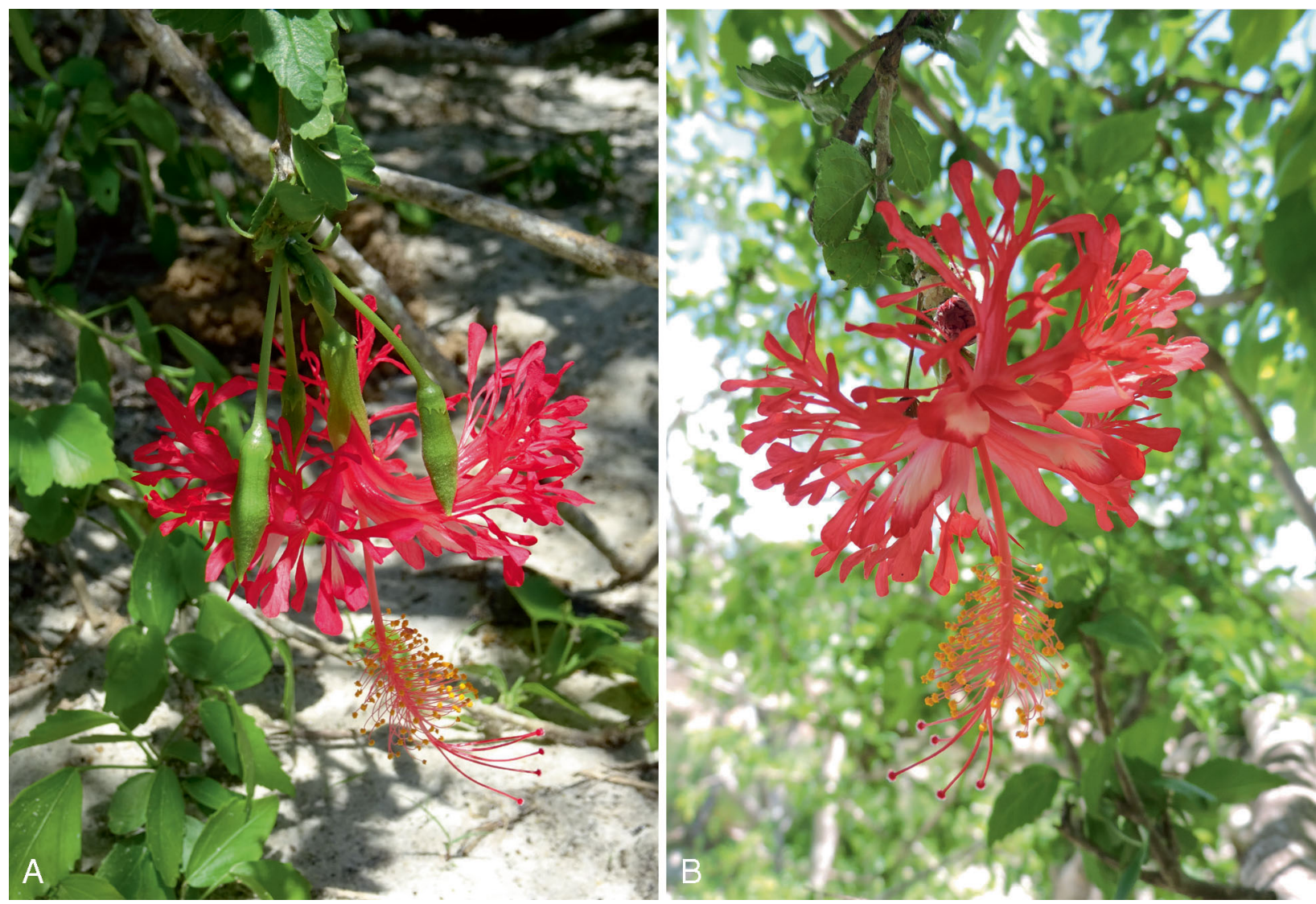

Fig. 3. Hibiscus hareyae. A leaves and inflorescence from above showing epicalyces; B flower from below showing white inner petal markings. From Suleiman et al. 5526 (K). PHOTOS: A IAIN DARBYSHIRE, B TORAL SHAH.

Despite this, large areas of coral rag remain with deciduous thicket more or less intact and so H. hareyae although threatened to some degree, does not seem at present at risk of imminent extinction across its range. We advise that some of this overlooked habitat and its threatened species be protected, perhaps as part of a national Important Plant Areas programme (Darbyshire et al. 2017). H. hareyae also ought to be conserved ex situ including through seedbanking and bringing into cultivation as an insurance policy against the species becoming extinct in the wild as is believed to be the case for other Tanzanian species such as Kihansia lovettii Cheek (Cheek 2004), which has never been seen since it was first collected, despite dedicated searches over several years.

PHENOLOGY. Hibiscus hareyae has been recorded as flowering from Nov. through to Feb. and July and August. Immature fruits have been observed in Nov., with the main fruiting period likely to extend from Dec. to March.

ETYMOLOGY. The specific epithet honours Dr Hareya Fassil (12 Jan. 1968 - present) in recognition of her work on conservation of plant genetic resources and the roles of traditional plant-based medicines in Africa.
VERNACULAR NAMES. Mgongonyoka (Swahili) and Kinyoka (Yau) (both Litchfield 5457); Lindi hibiscus (English).

NOTES. The holotype of Hibiscus hareyae is barcoded K000240493. It consists of two short stems both with flowers. It is mounted in the top righthand corner of a sheet at Kew with the pencilled label in the hand of Kirk, separated at the very base of the sheet, also on the right-hand side. Above this label is a separate collection, a paratype, barcoded K000593146, of a single flower in a packet annotated in the hand of $\mathrm{J}$. Hooker "Lindi, E.Africa, Dr Kirk, Nov. 1877" to which the barcode K000593146 has been assigned. To the left of the label is a larger packet containing the folded manuscript note by Kirk that was published as Kirk \& Oliver (1877). It is annotated in the hand of Oliver "Memorandum by Dr Kirk (18 Nov/74) to accompany specimens of Hibiscus from Mombasa" and "To be returned to Prof. Oliver".

Below the holotype is a label in the hand of Oliver stating "Sir J. Kirk distinguishes 2 vars (letter 10 Jan. 84). 1 from Kilwa (South! Shrub erect, often leafless at flowering- unjointed in pedicel- this is the var. sent herewith. Recd. At Kew/84." 


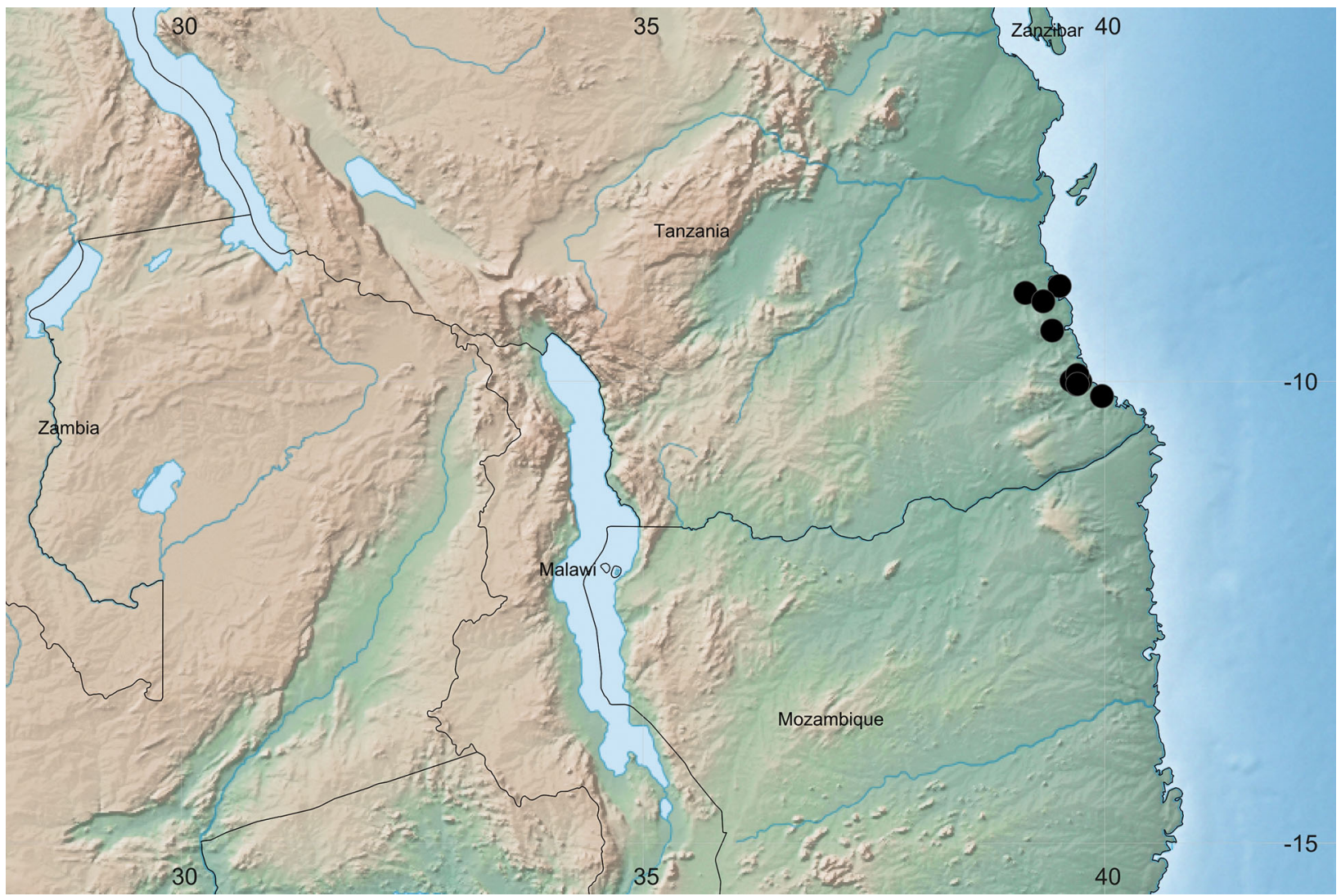

Map 1. Hibiscus hareyae. Global distribution map.

Hibiscus hareyae is similar to H. schizopetalus, and we postulate that both species are likely ancestral within sect. Lilibiscus. It is likely that $H$. hareyae shares a recent common ancestor with $H$. schizopetalus since they are in geographic proximity, and are so morphologically similar that they have been considered to be conspecific for 150 years. We hypothesise that a single population formerly extended along the coast from Kenya to southern Tanzania, adapting to the different local environments at northern and southern extremes, becoming separated from each other due to extinction of the intervening populations. The northern evergreen plants, i.e. $H$. schizopetalus are confined to the shady, damp understorey of coastal semi-evergreen forest of hills, especially Kaya forests, while the southern (H. hareyae) is restricted to the drier habitats of deciduous coastal thickets, and appear to be more xerophilous, with smaller leaves and are at least partly and briefly themselves deciduous. Similar species-pair disjunctions between SE Kenya and S-Central Tanzania are seen in the genus Ancistrocladus (Cheek et al. 2000). New species to science continue to be discovered steadily in Tanzania (e.g. Cheek \& Bridson 2019), including new taxa of Hibiscus e.g. H. kabuyeana Mwachala (Mwachala 2009) and $H$. vitifolius subsp. lukei (Mwachala \& Cheek 2003).

\section{Deciduous thicket on coral rag and the Lindi centre of endemism}

Clarke (2001) documented the Lindi local centre of endemism, within which falls the entire global distribution of Hibiscus hareyae. Forty to 91 vascular plant species are recorded as being unique to this area, focussed on the dissected plateaux inland of Lindi. These plateaux are, southwards from the Rufiji River, the Matumbi and Kichi Hills, the Ruwawa and Mbwalawala plateaux, a series of plateaux inland of Lindi, and the Makonde plateau (Clarke 2001). This row of four large upland massifs rising to an elevation of $945 \mathrm{~m}$ dominate the coastal hinterland of Tanzania. Although Clarke included the coastal lowlands in his centre, his focus is on forest, and coastal thicket is not mentioned as a habitat for endemics or as a conservation priority. Coastal thickets on coral rag in southern Tanzania appear to be understudied. Although $H$. hareyae is spectacular in flower over many months, it was not recollected in the 56 years between 1877 (Kirk s.n.) and 1934 (Schlieben). Another species restricted to this habitat in the Lindi area is Barleria laceratiflora Lindau, known from only two collections (Darbyshire et al. 2010: 406). Limestone habitats in Africa such as coral rag can often host narrowly endemic species of conservation importance (Cheek et al. 2019). 


\section{Dr John Kirk}

The collector of the type and first three specimens of Hibiscus hareyae, Dr John Kirk, was a British surgeon, who was a life-long friend of Joseph Hooker, Director of the Royal Botanic Gardens, Kew. He became a keen and observant naturalist, and following five years in central Africa as David Livingstone's chief officer on the second Zambezi expedition, he accepted the post of surgeon and Vice-Consul, Zanzibar (1866 - 1886), during which time he visited Kilwa (1868) and Mombassa, collecting the specimens of $H$. schizopetalus and $H$. hareyae referred to in this paper. He rarely published his own discoveries of botanical novelties, preferring to "hand them over to Kew" (Polhill \& Polhill 2015: 242 - 244; Goyder 2014).

\section{Early horticultural references}

In his letter (30 Jan. 1884) to Sir William ThiseltonDyer (Kew Gardens), Kirk indicated that he was planning on propagating cuttings of the southern variety' to send to Kew, but an examination of Kew's records indicates that these were never received. Hibiscus hareyae has high ornamental potential (Fig. 3), and Kirk considered the Kilwa (southern Tanzania) shrub better suited to cultivation than the larger, scrambling $H$. schizopetalus from Mombasa (Kenya). Ironically, H. schizopetalus has become a widely planted ornamental for the tropics/sub-tropics whereas $H$. hareyae appears unknown in cultivation.

\section{Acknowledgements}

The authors thank David Mabberley for suggesting the collaboration that led to this paper and Roy Gereau (Director of Tanzania Botanical Research and Conservation Programme, Africa and Madagascar, Missouri Botanical Garden) for his valuable assistance. Iain Darbyshire of the Royal Botanic Gardens, Kew, asked to look out for this species on a visit to coastal southern Tanzania with his doctoral student Toral Shah and their Tanzanian colleagues Haji. O. Suleiman and Y. S. Mbailwa, in early 2020, is profoundly thanked for his success in this endeavour, and for the resulting detailed ecological and populational data and photographs that feature in this paper. We also thank Kaj Vollesen, RBG, Kew for discussion of the ecology of the Lindi area. Xander van der Burgt kindly produced the distribution map. We acknowledge the generous help of the following organisations and individuals in providing information, assistance, images and access to botanical specimens: the Natural History Museum London, UK; University of Dar es Salaam Herbarium, Tanzania; Missouri Botanical Garden and Fairchild Tropical Botanical Garden Herbarium, USA), Mr Quentin Luke (East African Herbarium, National Museums of Kenya, Kenya), Mr John Ndege (Migombani Botanic Garden, Tanzania), Ms Kirsty Shaw and Dr Paul Smith (Botanic Gardens Conservation International).

The Keidanren Nature Conservation Fund through a grant to Botanic Gardens Conservation International has been supporting the 'Developing conservation horticulture and conserving threatened Hibiscus species in the Asia-Pacific Islands region' and the first author's research on Hibiscus.

Open Access This article is licensed under a Creative Commons Attribution 4.0 International License, which permits use, sharing, adaptation, distribution and reproduction in any medium or format, as long as you give appropriate credit to the original author(s) and the source, provide a link to the Creative Commons licence, and indicate if changes were made. The images or other third party material in this article are included in the article's Creative Commons licence, unless indicated otherwise in a credit line to the material. If material is not included in the article's Creative Commons licence and your intended use is not permitted by statutory regulation or exceeds the permitted use, you will need to obtain permission directly from the copyright holder. To view a copy of this licence, visit http://creativecommons.org/ licenses/by/4.0/.

\section{References}

Beentje H. \& Cheek, M. (2003). Glossary. In H. J. Beentje, (ed.), Flora of Tropical East Africa. Balkema, Lisse.

Boulger, G. S. (1879). Hibiscus rosa-sinensis var. schizopetalus. Gard. Chron 12: 372.

Cafferty, S. \& Cheek, M. (1996). Hibiscus fragilis. Curtis's Bot. Mag. 13210 - 214, fig. 306.

Cheek, M. (1989). Lectotypification and authorship of Hibiscus schizopetalus (Malvaceae). Taxon 38: 261 - 263. (2004). Kupeaeae, a new tribe of Triuridaceae from Africa. Kew Bull. 58: 939 - 949. https://doi.org/ $10.2307 / 4111207$

\& Bridson, D. M. (2019). Three new threatened Keetia species (Rubiaceae), from the forests of the Eastern Arc Mts, Tanzania. Gard. Bull. Singapore 71 (Suppl. 2): 155 - 169. https://doi.org/10.26492/ gbs71 (suppl.2).

, Cafferty, S. \& Staniforth, M. (1998). Hibiscus kokio subsp. saintjohnianus. Curtis's Bot. Mag. t. 352, pp. $236-241$.

Frimodt-Moeller, C. \& Hoerlyck, V. (2000). A new submontane species of Ancistrocladus from 
Tanzania. Kew Bull. 55: 207 - 212. https://doi.org/ $10.2307 / 4117778$

, Haba, P. K. \& Cisse, S. (2020). Hibiscus fabiana

sp. nov. (Malvaceae) from the Guinea Highlands (West Africa). Blumea 65: 69 - 74. https://doi.org/ 10.3767/blumea.2020.65.01.08

, Luke, Q., Matimele, H., Banze, A. \& Lawrence, P. (2019). Cola species of the limestone forests of Africa, with a new, endangered species, Cola cheringoma (Sterculiaceae), from Cheringoma, Mozambique. Kew Bull. 74: 52. https://doi.org/ 10.1007/S12225-019-9840-3

Clarke, G. P. (2001). The Lindi local centre of endemism in SE Tanzania. Syst. Geogr. Pl. 71: 1063 - 1072.

Darbyshire, I., Anderson, S., Asatryan, A., Byfield, A., Cheek, M., Clubbe, C., Ghrabi, Z., Harris, T., Heatubun, C. D., Kalema, J., Magassouba, S., McCarthy, B., Milliken, W., Montmollin, B. de, Nic Lughadha, E., Onana, J. M., Sardou, D., Sarbu, A., Shrestha, K. \& Radford, E. A. (2017). Important Plant Areas: revised selection criteria for a global approach to plant conservation. Biodivers. Conserv. 26: 1767 - 1800. https://doi.org/10.1007/ s10531-017-1336-6.

, Vollesen, K. \& Kelbessa, E. (2010). Acanthaceae (Part 2.) In: H. J. Beentje (ed.), Flora of Tropical East Africa, Royal Botanic Gardens, Kew.

Exell, A. W. (1961). Malvaceae. In: Flora Zambesiaca 1 (2): 470. London.

Goyder, D. (2014). Lectotypification of Musa livingstoniana (Musaceae). Kew Bull. 69: 9529.

Hooker, J. D. (1880). Hibiscus schizopetalus. Bot. Mag. 106 t. 6524.

IPNI (continuously updated). The International Plant Names Index. http://ipni.org/. (Accessed 25 Jan. 2020).

IUCN (2012). IUCN Red List Categories and Criteria: Version 3.1. Second edition. IUCN, Gland and Cambridge.

Kew Herbarium Catalogue (continuously updated). https://apps.kew.org/herbcat/gotoHomePage.do (Accessed 14 Dec. 2019).
Kirk, J. (1884). Letter from Sir John Kirk (Zanzibar) to Sir William Thiselton-Dyer (Kew); 30 Jan 1884. Kew Archives, Directors' Correspondence 4 pp.

\& Oliver, D. (1877). Note on specimens of Hibiscus allied to H. rosa-sinensis, L., collected in E. Tropical Africa. J. Linn. Soc., Bot. 15: 478 - 480.

Masters, M. (1879). The fringed hibiscus. Gard. Chron. 12: $272-273$, ig. 45 (p. 273).

Mwachala, G. (2009). Hibiscus pp. 31 - 75. In: B. Verdcourt \& G. Mwachala, Malvaceae. Flora of Tropical East Africa. Royal Botanic Gardens, Kew.

\& Cheek, M. (2003). Hibiscus vitifolius subsp. lukei (Malvaceae), a new taxon from Kenya. Kew Bull. 58: 499 - 501. https://doi.org/10.2307/4120636

Pfeil, B. E., BruBak, C. L., Craven, L. A. \& Crisp, M. D. (2002). Phylogeny of Hibiscus and the tribe Hibisceae (Malvaceae) using chloroplast DNA sequences of $n d h F$ and the rpl16 intron. Syst. Bot. 27: $333-350$.

Polhill, D. \& Polhill, R. (2015). East African Plant collectors. Kew Publishing.

POWO (2020). Plants of the World Online. Facilitated by the Royal Botanic Gardens, Kew. Published on the Internet; http:/ /www.plantsoftheworldonline.org/ (Accessed 1 Feb. 2020).

Thiers, B. (continuously updated). Index Herbariorum. http://sweetgum.nybg.org/science/ih/

Thistleton-Dyer, W. D. (1879). Hibiscus rosa-sinensis var. schizopetalus. Gard. Chron. 11: 568.

Thomson, L. A. J. \& Braglia, L. (2019). Review of Fiji Hibiscus (Malvaceae-Malvoideae) Species in Section Lilibiscus. Pacific Sci. 73: 79 - 121.

Tropicos.org. (2020). Missouri Botanical Garden. Published on the internet; http://www.tropicos.org (Accessed 27 June 2020).

\section{Publisher's Note}

Springer Nature remains neutral with regard to jurisdictional claims in published maps and institutional affiliations. 